\title{
Application of Rasch Model to Develop a Questionnaire for Evaluating the Quality of Teaching for Students' Creativity Development
}

\author{
Thi Le Thuy Bui \\ Hanoi National University of Education, Hanoi, Vietnam \\ https://orcid.org/0000-0002-4561-612X \\ Vyacheslav I. Kazarenkov \\ Peoples' Friendship University of Russia, Moscow, Russia \\ https:// orcid.org/0000-0002-2808-6526 \\ Van De Tran \\ Can Tho University of Medicine and Pharmacy, Can Tho, Vietnam \\ https://orcid.org/0000-0003-0421-5079
}

\begin{abstract}
The purpose of this research is to develop a questionnaire for evaluating the quality of teaching for creativity development. We use three methods for creating the questionnaire, namely, interviews, literature review, and expert consultation. The Rasch model was applied to assess the psychometric properties of the questionnaire in the first phase with the participation of 112 students. The results of the study indicated that all items had a point-measure correlation coefficient ranging between 0.312 and 0.757 , Infit and Outfit MNSQ values were in the range of 0.62 to 1.54 , item difficulty values were in the range from 1.54 to 1.12 . The overall reliability index of the questionnaire was 0.955 , the separation was 4.582, the scale's number of strata was 6.442 . Cronbach's alpha coefficient of the scale was 0.963 . The results of the study showed that the questionnaire was in good compliance with the Rasch model requirements. We used the questionnaire to assess the current status of teaching for creativity development in the teaching of Pedagogy in the second phase. This phase involved 300 first- and second-year students who were studying "Pedagogy" and they were grouped in 10 groups. A total of 10 teachers were evaluated, 1 teacher was evaluated by 1 group. The results showed that the quality of teachers' teaching for creativity development was at an acceptable level. We believe that teachers' preparation according to the evaluation criteria for teachers' quality teaching for creativity development is needed to improve teachers' teaching for students' creativity development.
\end{abstract}

Keywords: Rasch model; Questionnaire; Development; Creativity; Teaching process 


\section{Introduction}

Creativity has a great role for each individual and society and is considered an important element of participation and contribution to life and society (Loveless, 2002). Creativity is increasingly seen as a vital attribute for work, thinking, and life in the $21^{\text {st }}$ century (Mehta, Henriksen, 2016). The continuous changes that modern society is experiencing are raising new demands on higher education on the way to achieving the goal of initiating and developing creativity as a part of students' personalities. In this sense, promoting creativity among students is considered a very important purpose in higher education (Sadeghi, Ofoghi, 2011; Hamed, Preece \& Hashim, 2016; Thuy et al., 2019; Bui, Kazarenkov, 2020). Creativity and innovation in education are not only regarded as an opportunity, but also a necessity. These are considered an unalienable part of the purpose of the present and future educational system (Ferrari, Cachia \& Punie, 2009).

The issues related to teaching and initiating creativity through education among students have been studied for over the past twenty years. Modern psychologists and educators believe that creativity can be taught (Shrivastava, 2016; Beghetto, Kaufman, 2014; Pang, 2015; Kaplan, 2019; Richardson, Mishra, 2018); Tran, Ho \& Hurle, 2016, Kazarenkov et al., 2020). Currently, educators are paying increasing attention to changes in the modern educational process and the role of teachers in the process of education. In this context, the teaching process has changed much in recent years and differs widely from what it was in the past (Biswas, 2011) to become in the form of discussions, seminars, projects, workshops, etc. The teachers have to play the role of moderators, facilitators, consultants, and tutors in a modern university. They should help, inspire, and encourage students whenever needed. Through these roles, the teachers create the conditions in which the independence, activity, and creativity of students are manifested. They require them to constantly change and adapt to the requirements and conditions of modern education. We can say that the teacher is a decisive factor who decides the education in general and students' creativity development in particular.

Teachers' teaching of creativity is among factors that would motivate the students to be creative. Although the focus on creativity in the teaching process has been increased since the 1990s, that did not yield the expected results (Craft, 2005; Beghetto, 2005). According to Shrivastava (2016), one of the main causes of this is related to teachers. Additionally, there were many studies all over the world on the formation and development of students' creativity along with instruments to measure the different aspects of teaching creativity. However, there is limited research on psychometric properties analyses of these instruments which measure the degree of teachers' quality teaching for creativity development.

One of the modern approaches that allow creating a measuring instrument with adequate validation and reliability is the Rasch model (Assanovich, 2012). The Rasch model allows to evaluate the quality of the attributes of the scale within the theoretical framework of point-measure correlation coefficient (PTMEA Corr), item's infit and outfit values, item's level of difficulty, reliability, and separation and strata statistics of the questionnaire. Therefore, it can guarantee the consistency of the of the analyzed factor structure. Additionally, the Rasch 
analysis provides multiple sources of evidence to test the quality of a scale. Furthermore, it not only tests theoretical constructs, but also clearly indicates the items that need to be adjusted or replaced to ensure the overall quality of the scale. In recent years, the use of this method to assess the psychometric properties of scales has grown rapidly in various fields. The purpose of this study is to develop and validate a questionnaire for evaluating teaching for creativity development based on the Rasch model and using it to assess the state of teaching for creativity development in the teaching process of discipline "Pedagogy" at Hanoi National University of Education, Vietnam.

\section{Literature Review and Theoretical Framework}

\subsection{Creativity and Teaching for Creativity Development}

Creativity is considered as a process involving the creation of new ideas (Esquivel, 1995) and is a potentiality that everyone can develop in any field (Trnka, Zahradnik \& Kuška, 2016; Glaveanu, 2018). Creativity refers to people's ability to solve problems and transform reality (UNESCO, 2015).

In recent decades, research on creativity has become the central issue of many different scientific fields. Developing students' creativity is becoming one of the most important goals in the modern global educational system (Shaheen, 2010; Pang, Plucker, 2012). Sternberg and Lubart (1999) place high value on novel and appropriate products of creativity. Glaveanu (2018) appreciates novelty, originality, significance, or value in creative results. Creativity arises as a result of the interrelation between many different internal (intelligence, creative thinking, abilities, internal motivation) and external (psychological atmosphere within the group in the process of interpersonal interaction, approaches in the educational process) factors. Glaveanu (2013) explores the interrelations between actors, actions, artifacts, audiences, and contexts in the creative process. Walia (2019) is interested in creative activities and the definition of creativity. Elisondo and Vargas (2019) pay attention to the relationships between people, processes, environments, and products. Creative processes involve interrelations between actors, actions, artifacts, audiences and contexts (Glaveanu, 2013). As Elisondo (2016) indicated, the process of human creativity is always associated with social context and other factors.

Recently, researchers have developed a special interest in the relationship between creativity and the psychological state of people. They believe that creativity affects human's health and well-being (Richard, 2010; Corner, Silvia, 2015; Benedek, Bruckdorfer \& Jauk, 2019). During and after creativity process, people feel happier, more active, relieved, relaxed, and satisfied (Silvia, et al., 2014; Conner, DeYoung \& Silvia, 2017). On the contrary, people achieve greater creative effectiveness when they feel energetic, excited, enthusiastic, and joyful (Benedek, Bruckdorfer \& Jauk, 2019; Elisondo, Vargas, 2019). These findings suggest that teachers should create positive emotions for students in the teaching process to increase the effectiveness of creativity development. This is closely related to building a learning environment that encourages the development of students' creativity.

Their creativity largely depends on teacher's practices. Therefore, the issues of teaching for creativity development have been attracting a lot of attention by 
researchers in education around the world. Teaching to develop creativity is a process of equipping learners with knowledge about the creative process and giving opportunities for them to express their creativity (NACCCE, 1999). In this context, researchers believe that encouraging learners to believe in their own creativity is important in teaching for creativity (Moran, 2010; Ferrari, Cachia \& Punie, 2009). Teaching for the development of creativity is inseparable from the assessment of (Tran, Ho \& Hurle, 2016).

Assessment is considered one of the most important factors to develop students' creativity (Tran, Ho \& Hurle, 2016; Ferrari, Cachia \& Punie, 2009). The fact of teaching at universities shows that assessment of lecturers inhibits the development of students' creativity due to many different factors. Traditional teachers often affect students' creative performance negatively, because they tend to restrain individual student independence $(\mathrm{Ng}, 2002)$. The creative expression of students in the learning process is considered nonconformist by teachers (Shrivastava, 2016). The aspect of building a learning environment that supports the creativity of learners has caught the attention of many researchers (Beghetto, Kaufman, 2014; Davies et al., 2013; Hong, Chang \& Chai, 2014; Richardson, Mishra, 2018). Some authors concur with the idea that the learning environment that encourages creativity includes conditions of the physical environment, learning atmosphere, and student engagement. Hence, the ideal environment is to give learners a sense of security, comfort, excitement, and confidence to share ideas and personal thoughts. Other authors focus on researching creative tools in teaching to develop learners' creativity. These include tools for curiosity (Engel, 2013; Starko, 2013; Conklin, 2012), imagination (Lehrer, 2012), creative thinking (Starko, 2013). Teaching methods to stimulate learners' creativity are also discovered by Rankin, Brown (2016). The authors emphasize the empowerment of the learners and the learners' willingness to participate in creative learning. This is seen as the key to the success of teaching methods for developing learners' creativity.

\subsection{Theoretical Concepts of Teaching for Creativity Development}

The number of definitions of creativity is enormous. Each researcher approaches the nature of creativity differently. But most they believe that creativity is a process of curiosity-exploring, imagining and thinking based on one's knowledge, experiences, emotions and motivations to generate original and effective products (Vygotsky, 2004; Runco et al., 2012). According to this definition, the three most important personal traits for the student's creative development are imagination, curiosity and creative thinking. They have a strong correlation in the creative process and are embodied in creative products.

Creativity requires inputs of knowledge, creative skills and attitude towards creativity. Knowledge about creative process, particular area and related areas are essential factors for creativity (Tran, Ho \& Hurle, 2016). Thus, to develop creativity for students in the teaching process, teachers need to really pay attention to these factors.

Teaching to develop creativity is a process of equipping learners with knowledge about the creative process and creating opportunities for them to express their creativity (NACCCE, 1999). Teaching for creativity development is 
a form of teaching aimed at developing the creative competence and behavior of students (Sahlberg, 2009) and is carried out in the teaching process (Gorshunova, Medvedev \& Razdorskaya, 2014). According to these researchers, teachers should set the goals of developing students' creative competencies in teaching goals. Teaching for the development of creativity is inseparable from the assessment of students' creativity (Tran, Ho \& Hurle, 2016).

Any teaching process includes the following factors: goals, content, methods, tools, forms, environment, teacher, students, results. Therefore, to evaluate teaching for creativity development, it is necessary to focus on the factors of the teaching process as well as the goal of the creative development of students. They are interwoven, mixed, and united in the teaching process and the learning outcomes. Therefore, evaluation of the quality of teaching for creativity development includes the following aspects: development of students' creativity; development of knowledge, skills, attitudes toward the discipline and interdisciplinary; teaching methods and tools; forms of teaching; classroom environment; classroom management and assessment of learning outcomes.

\subsection{Rasch Model}

In the 1950s the concept of the item response theory (IRT) was first proposed by Frederic Lord (Lord, 1952). IRT includes mathematical models to explore validity and reliability of the questionnaire construct. Among IRT models, the Rasch model is most commonly applied and its theoretical basis is a description of the association between item difficulty and person's ability (Spinou, et al., 2017).

Currently, the Rasch model is considered an effective and modern approach for assessing the validation and reliability of a new scale that is being used in various scientific fields (Assanovich, 2012). For example, the Rasch model is used to explore psychometric properties of measurement scales such as medication counseling quality (Tran, Dorofeeva \& Loskutova, 2018); life (Tennant, McKenna \& Hagell, 2004); teachers' content knowledge (Jüttner, Boone, Park \& Neuhaus, 2013). It is also commonly applied in assessing psychometric properties of the scales being used today, such as claim evaluation tools (Austvoll-Dahlgren, et al., 2017) and creative achievement questionnaire (Wang, Ho, Cheng \& Cheng, 2014).

The more society develops, the more of new aspects of scientific research arise. Meanwhile, the previous tools and scales are no longer suitable for application to research in new issues. Therefore, the need to develop new scales is increasing. The role of the Rasch model in modern science is more widely accepted in various fields. This research contributes to the development of the teaching evaluation aspect of the development of creativity. The questionnaire is not only for evaluating the pedagogical activity of teachers but also constructed for managing the quality of education. Based on this questionnaire, educators, and education management organizations can have clear directions for enhancing the creative competence of students as well as the quality of education in general. 


\section{Methodology \\ Participants.}

The current study was conducted in two phases at Hanoi National University of Education, Vietnam. In the first phase, 20 teachers and 30 third-year students of faculty of psychology and education participated in the interviews on the criteria for assessing the quality of teaching for creativity development and 6 educational experts at 2 universities in Hanoi, Vietnam assessed the quality of the questionnaire "evaluation of the quality of teaching for creativity development". Then the questionnaire was used to survey the assessment of 112 students of faculty of psychology and education. In the second stage, a research survey was conducted to assess the current situation of teaching for creativity development in the teaching of Pedagogy. This phase involved 300 first- and second-year students who were grouped in 10 groups and each group evaluated one teacher. Thus, a total of 10 teachers were evaluated.

\section{Procedures.}

In the interview study we invited teachers who research and teach in psychological and educational sciences and 30 third-year students of the faculty of psychology and education. They are selected at random to answer openended question "Which criteria should be used to assess the quality of teaching for creativity development?". We conducted face-to-face interviews in the classroom. All responses were carefully recorded and analyzed separately, then divided by themes.

In the expert consultation method, we sent the questionnaire to the experts via email. The experts evaluated the structure, content as well as evaluation criteria of the questionnaire.

In the research to assess the quality of the questionnaire "Evaluation of the quality of teaching for creativity development" based on the Rasch model, we invited 112 students of psychology and education. Questionnaires were distributed to students and were collected as soon as they finished their assessment.

In the research survey on the current situation of teaching for creativity development in the teaching of Pedagogy, we have invited 300 first- and secondyear students of different faculties. They came from 10 different groups. Each group evaluated one teacher who has taught the discipline "Pedagogy". Student identification information was not disclosed to ensure the objectivity of the assessment results.

\section{Design and model.}

We used both qualitative and quantitative methods in this study. The qualitative methods included interviews, expert consultation and analysis and synthesis of previous studies related to students' creativity development topics in the learning process. A phenomenological approach used to explore the perceptions, perspectives and beliefs of teachers and students about the criteria for assessing the quality of teaching for creativity development. It allowed us to identify the specific perspectives of the respondents based on their perceptions and experience. 
The quantitative methods involved the Rasch analysis and research survey method. We assessed the psychological attributes of the questionnaire "Evaluation of the quality of teaching for creativity development" within the theoretical framework of point-measure correlation coefficient (PTMEA Corr), item's infit and outfit values, item's level of difficulty, reliability, and separation and strata statistics based on the Rasch model. It was applied using BIGSTEPS version 2.82 and jMetrik software version 4.0.6. Additionally, we used the survey method to assess the current situation of teaching for creativity development in the teaching of Pedagogy. The obtained results were processed using IBM SPSS Statistics software version 20 for descriptive statistics (frequency, mean). Figure 1 shows a model that represents the research methods.

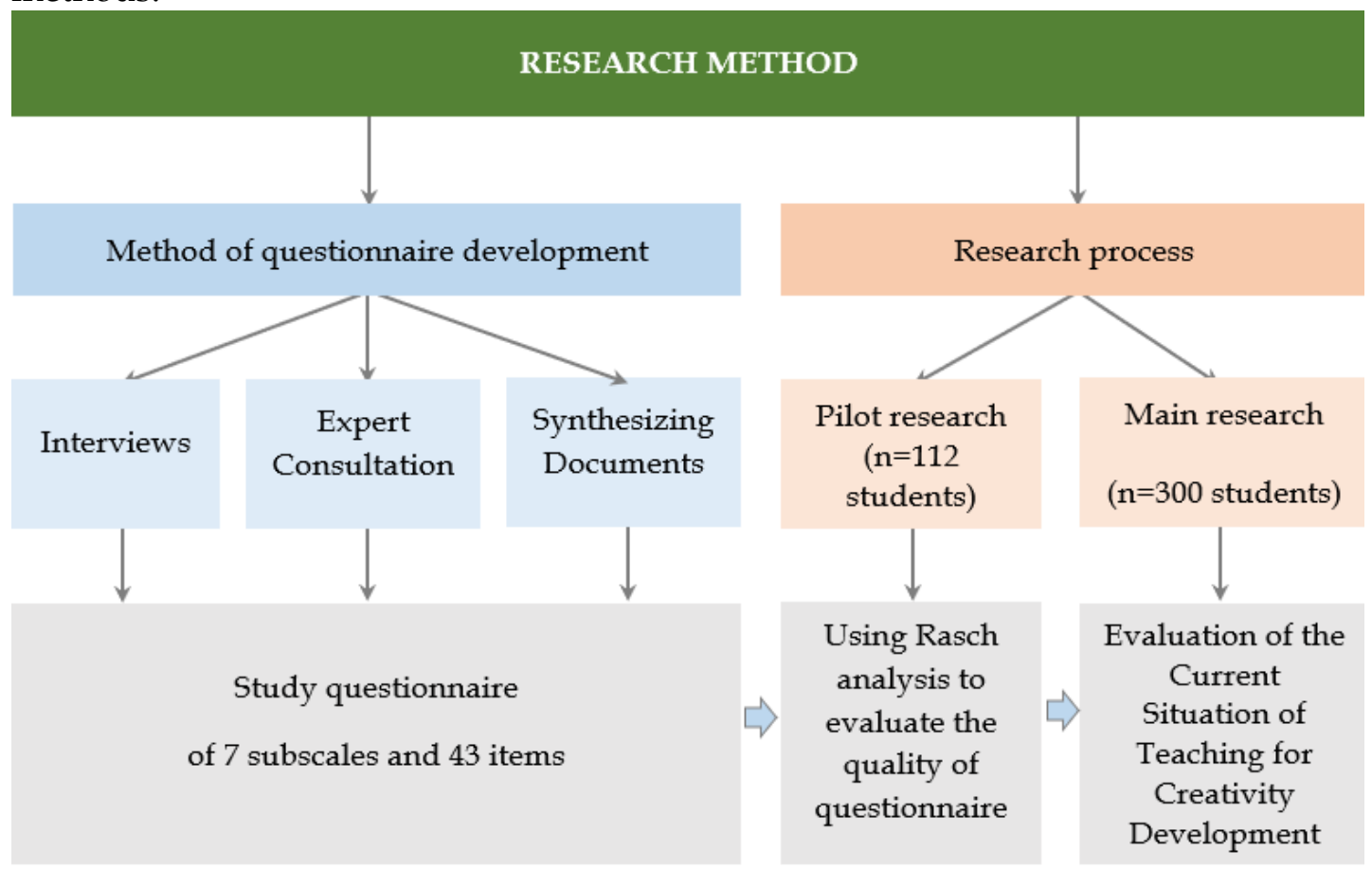

Figure 1: Model of Research Methods.

\section{Research Results}

4.1. Developing a Questionnaire "Evaluation of the Quality of Teaching for Creativity Development" Based on The Rasch Model

Based on the implementation of three methods, namely, interviewing, literature review, and expert consultations, we developed "Evaluation of the quality of teaching for creativity development Questionnaire" (see Appendix A). The questionnaire contains 43 items that reflect the quality of teaching for creativity development in 7 subscales: subscale I-Development of students' creativity (items 1-14); subscale II-Development of knowledge, skills, attitudes toward the discipline and interdisciplinary (items 15-24); subscale III-Teaching methods and tools (items 25-29); subscale IV-Forms of teaching (item 30); subscale V-Classroom environment (items 31-34); subscale VI-Classroom management (items 35-37); subscale VII-Assessment of learning outcomes (items 38-43). Each item was evaluated on a five-point quality Likert scale: 1Very Poor, 2- Poor, 3- Acceptable, 4-Good, and 5-Very good (Brown, 2010). The 
questionnaire considered as a tool for evaluating teaching for creativity development that allows us to determine the degree of achievement of teachers in the development of students' creative competence.

Table 1: Mean Score, Item's Difficulty, Fit Statistics and Point Measure Correlation Coefficient ( $\mathrm{N}=108$ students)

\begin{tabular}{|c|c|c|c|c|c|c|}
\hline Subscale & Item & $\begin{array}{l}\text { Mean } \\
\text { score }\end{array}$ & Difficulty & $\begin{array}{c}\text { Infit } \\
\text { MnSq }\end{array}$ & $\begin{array}{l}\text { Outfit } \\
\text { MnSq }\end{array}$ & $\begin{array}{c}\text { PTMEA } \\
\text { Corr }\end{array}$ \\
\hline \multirow{14}{*}{$\begin{array}{l}\text { I. Development of students' } \\
\text { creativity }\end{array}$} & 1 & 3.56 & 0.34 & 0.62 & 0.62 & 0.712 \\
\hline & 2 & 3.44 & 0.60 & 1.36 & 1.37 & 0.571 \\
\hline & 3 & 3.90 & -0.39 & 1.28 & 1.27 & 0.342 \\
\hline & 4 & 3.50 & 0.47 & 1.03 & 1.02 & 0.645 \\
\hline & 5 & 3.45 & 0.57 & 1.08 & 1.09 & 0.716 \\
\hline & 6 & 3.38 & 0.72 & 0.94 & 0.93 & 0.626 \\
\hline & 7 & 3.43 & 0.62 & 0.92 & 0.91 & 0.757 \\
\hline & 8 & 3.23 & 1.01 & 1.15 & 1.16 & 0.540 \\
\hline & 9 & 3.19 & 1.11 & 0.98 & 0.98 & 0.672 \\
\hline & 10 & 3.22 & 1.03 & 1.47 & 1.48 & 0.571 \\
\hline & 11 & 3.32 & 0.83 & 1.01 & 1.00 & 0.668 \\
\hline & 12 & 3.41 & 0.66 & 1.54 & 1.52 & 0.585 \\
\hline & 13 & 3.58 & 0.30 & 0.88 & 0.87 & 0.724 \\
\hline & 14 & 3.59 & 0.28 & 0.87 & 0.87 & 0.635 \\
\hline \multirow{10}{*}{$\begin{array}{l}\text { II-Development of } \\
\text { knowledge, skills, attitudes } \\
\text { toward the discipline and } \\
\text { interdisciplinary work }\end{array}$} & 15 & 3.56 & 0.34 & 0.96 & 0.97 & 0.588 \\
\hline & 16 & 3.59 & 0.28 & 0.89 & 0.91 & 0.575 \\
\hline & 17 & 3.31 & 0.85 & 0.80 & 0.82 & 0.627 \\
\hline & 18 & 3.33 & 0.81 & 0.68 & 0.69 & 0.653 \\
\hline & 19 & 3.59 & 0.28 & 0.83 & 0.85 & 0.589 \\
\hline & 20 & 3.18 & 1.12 & 0.75 & 0.75 & 0.566 \\
\hline & 21 & 4.06 & -0.79 & 0.67 & 0.67 & 0.708 \\
\hline & 22 & 3.80 & -0.16 & 1.04 & 1.02 & 0.427 \\
\hline & 23 & 3.85 & -0.29 & 0.90 & 0.93 & 0.488 \\
\hline & 24 & 3.55 & 0.38 & 1.11 & 1.10 & 0.531 \\
\hline \multirow{5}{*}{$\begin{array}{l}\text { III-Teaching methods and } \\
\text { tools }\end{array}$} & 25 & 3.81 & -0.20 & 0.79 & 0.78 & 0.692 \\
\hline & 26 & 4.04 & -0.72 & 0.89 & 0.84 & 0.656 \\
\hline & 27 & 3.75 & -0.06 & 0.78 & 0.80 & 0.618 \\
\hline & 28 & 3.85 & -0.29 & 0.83 & 0.81 & 0.635 \\
\hline & 29 & 4.07 & -0.81 & 0.85 & 0.81 & 0.618 \\
\hline IV-Forms of teaching & 30 & 4.34 & -1.54 & 1.21 & 1.20 & 0.463 \\
\hline \multirow{4}{*}{$\mathrm{V}-$ Classroom environment } & 31 & 4.09 & -0.86 & 0.82 & 0.82 & 0.685 \\
\hline & 32 & 3.96 & -0.54 & 0.96 & 0.94 & 0.642 \\
\hline & 33 & 3.99 & $\begin{array}{l}-0.61 \\
\end{array}$ & 0.99 & 1.02 & 0.604 \\
\hline & 34 & 4.06 & -0.77 & 1.44 & 1.42 & 0.437 \\
\hline \multirow{3}{*}{$\begin{array}{l}\mathrm{VI}-\text { Classroom } \\
\text { management }\end{array}$} & 35 & 3.79 & -0.14 & 1.39 & 1.39 & 0.312 \\
\hline & 36 & 3.81 & -0.18 & 0.80 & 0.81 & 0.629 \\
\hline & 37 & 4.24 & -1.25 & 0.72 & 0.72 & 0.672 \\
\hline \multirow{6}{*}{$\begin{array}{l}\text { VII-Assessment of learning } \\
\text { outcomes }\end{array}$} & 38 & 3.97 & -0.56 & 1.28 & 1.26 & 0.506 \\
\hline & 39 & 3.75 & -0.06 & 1.42 & 1.36 & 0.605 \\
\hline & 40 & 4.03 & -0.70 & 1.25 & 1.34 & 0.628 \\
\hline & 41 & 4.03 & -0.70 & 0.95 & 0.93 & 0.682 \\
\hline & 42 & 3.95 & -0.52 & 0.93 & 0.92 & 0.675 \\
\hline & 43 & 3.94 & -0.48 & 0.88 & 0.87 & 0.709 \\
\hline
\end{tabular}


This questionnaire was used to survey the assessment of teachers' teaching for creativity development by 112 students. Results were analyzed using BIGSTEPS version 2.82 and jMetrik software version 4.0.6 (for Rasch analysis). For conducting Rasch analysis, it is required a sample size with at least 100 participants. Therefore, this study sample of 112 students was considered as appropriate (Jackson, et al., 2020). Person fit statistic was conducted to find out outliers (misfitting persons) among 112 students. The result of the person fit statistics yielded that four students (No 38, 98, 105, and 109) were found as unfit persons because of their Infit and Outfit MnSq values >2.0. Therefore, the persons were removed from the study data. After eliminating these four persons, all the remaining students were found to be within the limits of acceptance. Infit MnSq values of 108 students ranged from 0.28 to 1.90 and Outfit MnSq value - from 0.27 to 1.90 . The analytical results of the psychometric properties of the questionnaire after removing misfit persons include validation assessment (item's difficulty, item fit statistics, point-measure correlation coefficient (PTMEA Corr), response category statistics) and reliability assessment (reliability index, separation index, strata index, and Cronbach's alpha) (see Tables 1, 2 and 3).

Item polarity was estimated by using the point-measure correlation coefficient (PTMEA CORR). The acceptable range of values is from 0.3 to 0.8 . Under this condition, the items are working in the same direction to measure a single basic construct (Allen, 2001). Any item with a PTMEA CORR value outside this range should be removed from the scale (Bond, Yan \& Heene, 2020). Table 1 shows that the polarity of items ranges from 0.312 to 0.757 . All items of the scale are in a scope consistent with the Rasch model which means that the questionnaire has a very good polarity of the correlated items.

Infit and outfit mean square (MnSq) values are important statistics when using the Rasch model. They allow the identification of items that fit the Rasch model accurately. The MnSq fit statistic values in the range from 0.5 to 1.5 are optimal (Meyer, 2014). MnSq values below 0.5 or between 1.5-2.0 are considered to be ineffective for building the scale. However, they do not violate the overall measuring qualities of the scale (Wright, Linacre, 1994). An item with an MnSq value greater than 2.0 should be removed from the scale. Table 1 shows that the Infit and Outfit MNSQ values of all items ranged from 0.62 to 1.54, which reflects that the questionnaire has very good construct validity. There isn't any item that needs editing or omitting.

Item difficulty indicates the relationship between the person's ability and the probability of a correct response (Baker, 2001). The range of the item difficulty value from -2.0 to 2.0 is considered appropriate in the Rasch model. An item with a difficulty value of less than -2.0 is interpreted as extremely simple, and an item with a difficulty value of more than 2.0 is considered extremely difficult (Assanovich, 2014). The results in Table 1 indicate that the difficulty values of all items were in the range from -1.54 to 1.12 . Thus, all 43 items of the scale had an acceptable difficulty value within the Rasch normative model. Among 43 items, item 9 which "students choose the most creative ideas to solve problems or create new products" (1.11) and item 20 which "development of the interdisciplinary skills" (1.12) proved to be the most difficult items. They reflect 
subscales, "development of students' creativity" and "development of knowledge, skills, attitudes of the discipline and interdisciplinary." This shows that in teaching for creativity development, process of organizing students to come up with solutions, ideas to solve problems and choose the most creative ideas among them is a difficult skill. Besides, the development of interdisciplinary skills is also a challenge for teachers. Maybe because the content of the subject is too much, the time for studying the subject is limited and the teachers don't have good pedagogical skills in organizing creative classes. Item 30 which "the teacher uses individual and group forms" (-1.54) and item 37 which "The teacher praises the good behavior and success of the students" (-1.25) were the easiest items. They reflect subscales: "forms of teaching" and "classroom management". This shows that in the teaching process, teachers often combine individual and group learning forms as well as promptly praise good behaviors of students.

Table 2: Response Category Statistics of Items for the Questionnaire (N=108 students)

\begin{tabular}{|l|l|l|l|l|}
\hline Category & Level & Threshold & Infit MnSq & Outfit MnSq \\
\hline 1 & Very poor & - & - & - \\
\hline 2 & Poor & -2.84 & 0.94 & 0.94 \\
\hline 3 & Acceptable & -0.95 & 1.02 & 1.02 \\
\hline 4 & Good & 0.82 & 1.04 & 1.02 \\
\hline 5 & Very good & 2.98 & 1.03 & 1.02 \\
\hline
\end{tabular}

The results of response category statistics of items for the questionnaire are shown in Table 2. Categories statistics found that there was a gradual increase in the difficulty level from category 1 (very poor) to 5 (very good). In other words, it is difficult for students to get a category score threshold of 5 rather than 4 . Similarly, category score threshold 4 is more difficult than $3,3>2$, and $2>1$. The large difference between the two successive categories is considered as good (>1.7). Additionally, the categories had good Infit and Outfit statistics, with acceptable values from 0.94 to 1.04 .

Table 3: Reliability, Separation Index and Strata Index, and Cronbach's Alpha (N=108 students)

\begin{tabular}{|c|c|c|}
\hline Index & Overall scale & Person \\
\hline Reliability & 0.955 & 0.961 \\
\hline Separation & 4.582 & 4.984 \\
\hline Number of strata & 6.442 & 6.979 \\
\hline Cronbach's alpha & 0.963 & - \\
\hline
\end{tabular}


The results of the reliability index and the separation are shown in Table 3. In the Rasch model, reliability values are in the range from 0 to 1 . If the value is less than 0.5 the item is considered of unacceptable reliability; 0.5 to 0.6 - poor; 0.6 to 0.7 - questionable; 0.7 to 0.8 - acceptable; 0.8 to 0.9 - good; and more than $0.9-$ very good reliability. The scale of reliability of this study was 0.955 and the persons' reliability was 0.961 , which is indicative of the questionnaire having very good reliability (range greater than 0.9 ) and items had good internal consistency in the measurement construct of scale.

According to Fisher (2007), separation values above 3 are considered good. The result presented in Table 3 shows that the separation of the scale was 4.582, separation of a person's ability was 4.984. As suggested by Assanovich (2014), an index of the number of strata of the scale greater than 1 is considered appropriate. And, naturally, higher strata values are considered more reliable. In this study, the scale's number of strata was separated into six distinct levels (6.442), strata of person's ability was 6.979. This indicated a very good level of the questionnaire's reliability in our study. Cronbach's alpha coefficient of the scale was also at a high level (0.963).

\subsection{Application of the Questionnaire in Assessing the Real Situation of Teaching for Creativity Development in the Teaching of Pedagogy.}

In the second stage, we have applied the questionnaire to assess the current situation of teaching for creativity development in the teaching of Pedagogy. This phase involved 300 first- and second-year students divided into 10 groups, 1 teacher was evaluated by 1 group (30 students). According to the guidelines provided by Johannessen, Tufte and Christoffersen (2010), the number of respondents should not be less than 30 people. The obtained results were processed using IBM SPSS Statistics software version 20 and are represented by the mean score of each subscale and each teacher (see Table 4).

Table 4 shows the degree of teaching for creativity development in the teaching of Pedagogy to be at an acceptable: 3.05. The subscales with the highest score were IV-Forms of teaching: 3.81 (rank 1); V-Classroom environment: 3.49 (rank 2); VII-Assessment of learning outcomes: 3.23 (rank 3). These are three aspects in which the teachers performed better than in other aspects. However, teachers still need to implement them more effectively in the teaching process to further develop students' creativity. The subscales with the lowest score were I-Development of students' creativity (2.73) and III - Teaching methods and tools (2.96). These are two aspects that need more attention from the teachers to perform better in the evaluation of the teaching process.

Table 4 also shows the degree of teaching for creativity development of 10 teachers at an acceptable level. We see that they have diverse average scores ranging from 3.02 to 3.08. However, this difference was negligible. At Hanoi National University of Education, the discipline "Pedagogy" is a compulsory common subject for pedagogical all students. Each class usually has from 100 to 120 students with different majors. The creativity development for students in the teaching process was not focused. Hence, the actual assessment of the teaching for creativity development is considered necessary to bring 
effectiveness to future experimental work. The results of detail assessment including each subscale and items for 10 teachers are shown in Appendix A (see Appendix A).

Table 4: The Degree of Teaching for Creativity Development in the Teaching of Pedagogy among 10 teachers ( $=300$ students)

\begin{tabular}{|c|c|c|c|c|c|c|c|c|c|c|c|}
\hline \multirow{2}{*}{ Subscale } & \multicolumn{10}{|c|}{ Teacher (Mean) } & \multirow{2}{*}{$\begin{array}{c}\text { Subscale } \\
\text { mean }\end{array}$} \\
\hline & 1 & 2 & 3 & 4 & 5 & 6 & 7 & 8 & 9 & 10 & \\
\hline $\begin{array}{l}\text { I-Development } \\
\text { of students' } \\
\text { creativity }\end{array}$ & 2.83 & 2.75 & 2.71 & 2.72 & 2.71 & 2.70 & 2.71 & 2.74 & 2.73 & 2.72 & 2.73 \\
\hline $\begin{array}{l}\text { II-Development } \\
\text { of knowledge, } \\
\text { skills, attitudes } \\
\text { toward the } \\
\text { discipline and } \\
\text { interdisciplinary } \\
\text { work }\end{array}$ & 3.16 & 3.14 & 3.23 & 3.25 & 3.20 & 3.11 & 3.18 & 3.18 & 3.11 & 3.05 & 3.16 \\
\hline $\begin{array}{l}\text { III-Teaching } \\
\text { methods and } \\
\text { tools }\end{array}$ & 2.88 & 2.91 & 2.80 & 2.99 & 2.87 & 2.78 & 2.99 & 3.07 & 3.17 & 3.11 & 2.96 \\
\hline $\begin{array}{l}\text { IV-Forms of } \\
\text { teaching }\end{array}$ & 3.90 & 3.77 & 3.73 & 3.83 & 3.80 & 3.93 & 3.77 & 3.67 & 4.03 & 3.67 & 3.81 \\
\hline $\begin{array}{l}\text { V-Classroom } \\
\text { environment }\end{array}$ & 3.44 & 3.45 & 3.47 & 3.41 & 3.43 & 3.48 & 3.61 & 3.62 & 3.55 & 3.43 & 3.49 \\
\hline $\begin{array}{l}\text { VI-Classroom } \\
\text { management }\end{array}$ & 2.99 & 2.94 & 2.97 & 3.14 & 3.13 & 3.09 & 3.22 & 3.24 & 3.10 & 3.08 & 3.09 \\
\hline $\begin{array}{l}\text { VII-Assessment } \\
\text { of learning } \\
\text { outcomes }\end{array}$ & 3.23 & 3.23 & 3.23 & 3.14 & 3.26 & 3.30 & 3.23 & 3.15 & 3.24 & 3.25 & 3.23 \\
\hline $\begin{array}{l}\text { Overall scale } \\
\text { mean for each } \\
\text { teachers }\end{array}$ & 3.06 & 3.03 & 3.03 & 3.05 & 3.04 & 3.02 & 3.07 & 3.08 & 3.07 & 3.03 & 3.05 \\
\hline
\end{tabular}

\section{Discussion}

The goal of current study is to clarify two research questions: 1) Does the questionnaire "evaluation of the quality of teaching for creativity development" conform to the requirements of the Rasch model? And 2) What is the current status of teaching for creativity development in the teaching of Pedagogy at Hanoi National University of Education, Vietnam?.

The questionnaire "evaluation of the quality of teaching for creativity development" contains 43 items. The Rasch model was applied to assess the quality of the questionnaire using BIGSTEPS version 2.82 and jMetrik software version 4.0.6. The measurement was carried out within the framework of the theory of point-measure correlation coefficient (PTMEA Corr), item's infit and outfit values, item's level of difficulty, reliability, and separation and strata statistics of the questionnaire. 
The acceptable range of PTMEA Corr values is from 0.3 to 0.8 (Allen, 2001). In this study 43 items had PTMEA Corr values between 0.312 and 0.757 . The MnSq fit statistic values in the range from 0.5 to 1.5 are optimal (Meyer, 2014). All items had Infit and Outfit MNSQ values in the range from 0.62 to 1.54. The range of the item difficulty value from -2.0 to 2.0 is considered appropriate in the Rasch model (Assanovich, 2014). All items had item difficulty values in the range from -1.54 to 1.12 . The scale reliability of this study was 0.955 and the persons' reliability was 0.961 . Separation values above 3 are considered good (Fisher, 2007). The separation of the scale was 4.582, separation of a person's ability was 4.984. An index of the number of strata of the scale greater than 1 is considered appropriate. And, naturally, higher strata values are considered more reliable (Assanovich, 2014). In this study, the scale's number of strata was separated into six distinct levels (6.442), strata of person's ability was 6.979 . Cronbach's alpha coefficient of the scale was also at a high level (0.963).

The Rasch analysis showed multiple sources of evidence to test the quality of the questionnaire. Results indicated that the questionnaire was in good compliance with the Rasch model requirements. It may be used to measure the quality of teaching for creativity development and improve teachers' teaching for creativity development in higher education.

We used the questionnaire to assess the current status of teaching for creativity development in the teaching of Pedagogy. The results showed that the degree of the teachers' teaching for creativity development at an acceptable level (3.05). This shows that students' creative capacity has not been developed in the teaching process.

In order to improve teachers' teaching for creativity development, we believe that it is necessary to do the following:

- Build an environment that encourages creative teaching and learning in universities.

- Organize teacher training on teaching for creativity development.

- Actively organize attractive creative activities associated with teaching and creative development goals in the classroom, in university as well as in society for students to participate.

\section{Recommendations}

Based on the analyzed results, we make the following recommendations for future research:

- It is necessary to organize the teacher training focusing on methods, tools, forms, building a classroom environment, assessment of learning outcomes for creative development.

- Equip students with knowledge and skills about creativity to motivate them to develop creative capacity in the learning process at the university.

- It is necessary to carry out empirical studies to determine the effectiveness of teachers' teaching for creativity development in enhancing learning outcomes and student developing creativity. 


\section{Conclusions}

In this study, the questionnaire "evaluation of the quality of teaching for creativity development" was created to assess the current status and improve teachers' teaching for creativity development. We used three methods to develop the questionnaire: interviewing, synthesizing documents, and expert consultation. It consisted of seven subscales: development of students' creativity; development of knowledge, skills, attitudes toward the discipline and interdisciplinary work; teaching methods and tools; forms of teaching; classroom environment; classroom management; assessment of learning outcomes. The items are rated on a five-point quality Likert scale.

The Rasch model was applied to assess the quality of the questionnaire using BIGSTEPS version 2.82 and jMetrik software version 4.0.6. The measurement was carried out within the framework of the theory of point-measure correlation coefficient (PTMEA Corr), item's infit and outfit values, item's level of difficulty, reliability, and separation and strata statistics of the questionnaire. The results showed that the questionnaire conformed closely with the Rasch model's requirements and may be used to measure the quality of teaching for creativity development in different subjects in higher education.

The questionnaire has been applied to assess the current status of teaching for creativity development in the teaching of Pedagogy at Hanoi National University of Education, Vietnam. The results showed that the degree of the teachers' teaching for creativity development at an acceptable level (3.05). Therefore, further research is needed to conduct experimental pedagogical work on the formation of students' creativity in the teaching of Pedagogy.

\section{References}

Allen, M. J., \& Yen W. M. (Eds.). (2001). Introduction to Measurement Theory. USA: Waveland Press.

Assanovich, M. A. (2014). The problem of scientific measurement in psychodiagnostics. J. Grodn. State Medical University, 1(45), 9-13.

Assanovich, M. A. (Ed.). (2012). Clinical psychodiagnostics. Minsk: "Belarus”.

Austvoll-Dahlgren, A., Guttersrud Ø., Nsangi, A., Semakula, D., \& Oxman, A. D. (2017). Measuring ability to assess claims about treatment effects: a latent trait analysis of items from the 'Claim Evaluation Tools' database using Rasch modelling. BMJ Open, 7(5), e013185. https:/ / doi.org/10.1136/bmjopen-2016-013185

Baker, F. B. (Ed.). (2001). The Basics of Item Response Theory (2nd ed.). USA: ERIC.

Beghetto, R. A. (2005). Does Assessment Kill Student Creativity? The Educational Forum, 69, 254-263.

Beghetto, R. A., \& Kaufman, J. C. (2014). Classroom contexts for creativity. High Ability Studies, 25(1), 53-69. http:/ / dx.doi.org/10.1080/13598139.2014.905247

Benedek, M., Bruckdorfer, R., \& Jauk, E. (2019) Motives for Creativity: Exploring the What and Why of Everyday Creativity. The Journal of Creative Behavior, 1-16. https:// doi.org/10.1002/jocb.396

Biswas, G. K. (2011). Technological Approach in Teaching History, Musings, 2, 127-129.

Bond, T. G., Yan, Z., \& Heene, M. (2020). Applying the Rasch Model (4th ed.). London: Routledge.

Brown, S. (2010). Likert scale examples for surveys. Retrieved from http://www.extension.iastate.edu/ag/staff/info/likertscaleexamples.pdf 
Bui, T. L. T., \& Kazarenkov, V. I. (2020). Q-Methodology: A New Way to Develop an Effective Teaching Model for the Development of Students' Creative Activity. International Journal of Innovative Technology and Exploring Engineering, 9(3), 14951501. https://doi.org/10.35940/ijitee.C8317.019320

Bui, T. L. T., Kazarenkov, V., Tran, V. D, Dorofeeva, V., \& Nguyen, T. (2019). Use of Qmethodology for studying students' creative activity. The European proceedings of social $\mathcal{E}$ behavioural sciences, 76(469), 3492-3496. Retrieved from https://www.futureacademy.org.uk/files/images/upload/SCTCMG2019FA46 9.pdf

Conklin, W. (Ed.). (2012). Strategies for Developing Higher-Order Thinking Skills, Grades 612. Huntington Beach, CA: Shell Educational Publishing.

Conner, T. S., DeYoung, C. G., \& Silvia P. J. (2017). Everyday creative activity as a path to flourishing. Journal of Positive Psychology, 13(2), 181-189. http://dx.doi.org/10.1080/17439760.2016.1257049

Conner, T., \& Silvia, P. (2015). Creative days: A daily diary study of emotion, personality, and everyday creativity. Psychology of Aesthetics, Creativity, and the Arts, 9(4), 463-470. https://doi.org/10.1037/aca0000022

Craft, A. (2005). Creativity in schools: Tensions and dilemmas. London: Routledge.

Davies, D., Jindal-Snape, D., Collier, C., Digby, R., Hay, P., \& Howe, A. (2013). Creative Learning Environments in Education - A Systematic Literature Review. Thinking Skills and Creativity, 8, 80-91. https:// doi.org/10.1016/j.tsc.2012.07.004

Elisondo, R. (2016). Creativity is always a social process. Creativity. TheoriesResearchvApplications, 3(2), 194-210. https://doi.org/10.1515/ctra-2016-0013

Elisondo, R. C., \& Vargas, A. (2019). Women's everyday creative activities: a qualitative study. Creativity. Theories - Research - Applications, 6(1), 91-111. https://doi.org/10.1515/ctra-2019-0006

Engel, S. (2013). The Case for Curiosity. Educational Leadership, 70, 36-40.

Esquivel, G. B. (1995). Teacher behaviours that foster creativity. Educational Psychology Review, 7(2), 185 - 202.

Ferrari, A., Cachia, R., \& Punie, Y. (2009). Innovation and Creativity in Education and Training in the EU Member States: Fostering Creative Learning and Supporting Innovative Teaching. JRC Technical Notes. Retrieved from http://ftp.jrc.es/EURdoc/JRC52374_TN.pdf

Fisher, W. (2007). Rating scale instrument quality criteria. Rasch Meas Trans, 21(1), 10871096.

Glaveanu, V. (2013). Rewriting the language of creativity: The five A's framework. Review of General Psychology, 17, 69-81. https://doi.org/10.1037/a0029528

Glaveanu, V. (2018). Educating which creativity? Thinking Skills and Creativity, 27, 25-32.

Gorshunova, N. K., Medvedev, N. V., \& Razdorskaya, O. V. (2014). The Significance of High School Teacher's Creativity for Innovation Pedagogical Practice. Journal of International Scientific Publications, 12, 607-614.

Hamed, P. K., Preece, A. S. D., \& Hashim, C. N. (2016). Factors influencing creative teaching among teachers in Islamic private schools in Kuala Lumpur. Proceedings of the International Conference on Education towards Global Peace. Retrieved from http://www.iium.edu.my/capeu2016/wp content/uploads/2017/02/03 1.pdf

Hong, H. Y., Chang, Y. H., \& Chai, C. S. (2014). Fostering a collaborative and creative climate in a college class through idea-centered knowledge-building. Instructional Science, 42(3), 389-407. http://dx.doi.org/10.1007/s11251-013-9289$\mathrm{y}$ 
Jackson, A., Rogerson, M., Le Grande, M., Thompson, D., Ski, C., Alvarenga, M., Amerena, J., Higgins, R., Raciti, M., \& Murphy, B. M. (2020). Protocol for the development and validation of a measure of persistent psychological and emotional distress in cardiac patients: The Cardiac Distress Inventory. BMJ Open, 10(6). http://dx.doi.org/10.1136/bmjopen-2019-034946.

Johannessen, A., Tufte, P. A., \& Christoffersen, L. (2010). Introduksjon til samfunnsvitenskapelig metode [Introduction to social science methodology] ( $4^{\text {th }}$ ed.). Oslo: Abstrakt forlag.

Jüttner, M., Boone. W., Park. S., \& Neuhaus. B. J. (2013). Development and use of a test instrument to measure biology teachers' content knowledge (CK) and pedagogical content knowledge (PCK). Educ Asse Eval Acc. http://dx.doi.org/10.1007/s11092-013-9157-y

Kaplan, D. E. (2019). Creativity in Education: Teaching for Creativity Development. Psychology, 10, 140-147. https://doi.org/10.4236/psych.2019.102012

Kazarenkov, V., Bui, T., Kazarenkova, T., \& Kameneva, G. (2020). Studying the development factors of students' creativity based on Q-methodology. Proceedings of the International Scientific Conference, 1, 333-340. http://dx.doi.org/10.17770/sie2020vol1.5144

Lehrer, J. (Ed.). (2012). Imagine: How Creativity Works. Boston, MA: Houghton Mifflin Harcourt.

Lord F. (Ed.). (1952). A Theory of Test Scores. Richmond, VA: Psychometric Corporation.

Loveless, A. M. (Ed.). (2002). Literature Review in Creativity, New Technologies and Learning: A report for Futurelab. Bristol: Futurelab.

Meyer, J. (Ed.). (2014). Applied measurement with jMetrik. New York: Routledge.

National Advisory Committee on Creative \& Cultural Education (Ed.). (1999) All our futures: creativity, culture and education. Report of the National Advisory Committee on Creative and Cultural Education. Sudbury: DfEE.

$\mathrm{Ng}$, A. K. (2002). The Development of a New Scale to Measure Teachers' Attitudes toward Students (TATS). Educational Research Journal, 17(1), 63-77.

Pang, W. (2015). Promoting creativity in the classroom: A generative view. Psychology of Aesthetics. Creativity, and the Arts, 9(2), 122-127.

Pang, W., \& Plucker, J. A. (2012). Recent transformations in China's economic, social, and education policies for promoting innovation and creativity. The Journal of Creative Behavior, 46, 247-273. http://dx.doi.org/10.1002/jocb.17

Rankin, J., \& Brown, V. (2016). Creative teaching method as a learning strategy for student midwives: A qualitative study. Nurse Education Today, 38, 93-100. http://dx.doi.org/10.1016/j.nedt.2015.12.009

Richards, R. (2010). Everyday creativity: Process and way of life - four key issues. In J. C. Kaufman \& R. J. Sternberg (Eds.), The Cambridge handbook of creativity (pp. 189215). New York: Cambridge University Press.

Richardson, C., \& Mishra, P. (2018). Learning Environments that Support Student Creativity: Developing the SCALE. Thinking Skills and Creativity, 27, 45-54. https:// doi.org/10.1016/j.tsc.2017.11.004

Runco, M. A., \& Jaeger, G. J. (2012). The Standard Definition of Creativity. Creativity Research Journal, 24, 92-96. http://dx.doi.org/10.1080/10400419.2012.650092

Sadeghi, A., \& Ofoghi, N. (2011). The psychological factors affecting students' creativity inside the class (CIC) (case study the University of Guilan, Iran). Procedia Social and Behavioral Sciences, 15, 263-270. https://doi.org/10.1016/j.sbspro.2011.03.084 
Sahlberg, P. (2009). The Role of Education in Promoting Creativity: Potential Barriers and Enabling Factors. In E. Villalba (Ed.), Measuring Creativity (pp. 337-344). Luxemburg: OPOCE.

Shaheen, R. (2010). Creativity and education. Creative Education, 1, 166-169. http://dx.doi.org/10.4236/ce.2010.13026

Shrivastava, S. (2016). Creativity and intelligence. International Journal of Recent Advances in Multidisciplinary Research, 3(3), 339-1344.

Silvia, P. J., Beaty, R. E., Nusbaum, E. C., Eddington, K. M., Levin-Aspenson, H., \& Kwapil, T. R. (2014). Everyday creativity in daily life: An experience-sampling study of "little c" creativity. Psychology of Aesthetics, Creativity, and the Arts, 8, 183-188. http://dx.doi.org/10.1037/a0035722

Spinou, A., Siegert, R. J., Guan, W., Patel, A. S., Gosker, H. R., Lee, K. K., Elston, C., Loebinger, M. R., Wilson, R., Garrod, R., \& Birring, S. S. (2017). The development and validation of the Bronchiectasis Health Questionnaire. Eur Respir J, 49(5): 1601532. http://dx.doi.org/10.1183/13993003.01532-2016

Starko, A. J. (Ed.). (2013). Creativity in the Classroom Schools of Curious Delight. New York: Routledge

Sternberg, R. J. \& Lubart, T. I. (1999). The concept of creativity: Prospects and paradigms. In R. J. Sternberg (Ed.), Handbook of creativity (pp. 3-15). New York: Cambridge University Press.

Tennant, A., McKenna. S. P., \& Hagell, P. (2004). Application of Rasch analysis in the development and application of quality of life instruments. Value in health, 7(Suppl 1): S22-S26.

Tran, L. T. B., Ho, N. T., \& Hurle, R. J. (2016). Teaching for Creativity Development: Lessons from a Preliminary Study of Vietnamese and International Upper (High) Secondary School Teachers' Perceptions and Lessons Plans. Creative Education, 7, 1024-1043. http://dx.doi.org/10.4236/ce.2016.77107

Tran, V. D., Dorofeeva, V. V., \& Loskutova, E. E. (2018). Development and validation of a scale to measure the quality of patient medication counseling using Rasch $\begin{array}{llll}\text { model. Pharmacy } & \text { Practice, } & 1327 .\end{array}$ https://doi.org/10.18549/PharmPract.2018.04.1327

Trnka, R., Zahradnik, M. Y., \& Kuška, M. (2016). Emotional Creativity and Real-Life Involvement in Different Types of Creative Leisure Activities. Creativity Research Journal, 28(3), 348-356.

UNESCO (2015). Cultural times The first global map of cultural and creative industries. Retrieved

from https://en.unesco.org/creativity/sites/creativity/files/cultural_times_the_first _global_map_of_cultural_and_creative_industries.pdf

Vygotsky, S. L. (2004). Imagination and Creativity in Childhood. Journal of Russian and East European Psychology, 42, 7-97.

Walia, C. (2019): A Dynamic Definition of Creativity. Creativity Research Journal, 31(3), 237-247. https://doi.org/10.1080/10400419.2019.1641787

Wang, C. C., Ho, H. C., Cheng, C. L., \& Cheng, Y. Y. (2014) Application of the Rasch Model to the Measurement of Creativity: The Creative Achievement Questionnaire. Creativity Research Journal, 26(1), 62-71. https://doi.org/10.1080/10400419.2013.843347 
Appendix A: The questionnaire "Evaluation of the Quality of Teaching for Creativity Development" and the results of detail assessment including each subscale and items for 10 teachers $(\mathrm{N}=300$ students)

\begin{tabular}{|c|c|c|}
\hline Item Content & Mean & SD \\
\hline \multicolumn{3}{|l|}{ I. Development of Students' Creativity } \\
\hline 1.1. Development of the ability of curiosity and discovery & 2.62 & 0.51 \\
\hline + Students ask questions and answer & 2.26 & 0.73 \\
\hline + The teacher asks questions, students answer & 2.97 & 0.76 \\
\hline 1.2. Development of imagination competence & 2.48 & 0.53 \\
\hline+ Creative imagination & 2.12 & 0.73 \\
\hline + Reproduced imagination & 2.83 & 0.78 \\
\hline 1.3. Development of the creative thinking competency & 2.35 & 0.51 \\
\hline + Students comment on scientific critical ideas & 2.25 & 0.72 \\
\hline $\begin{array}{l}\text { + Students choose the most creative ideas to solve problems or } \\
\text { create new products }\end{array}$ & 2.45 & 0.69 \\
\hline 1.4. Students have creative products & 2.56 & 0.4 \\
\hline + Creative ideas/solutions & 2.42 & 0.71 \\
\hline + Creative pictures, diagrams, products & 2.42 & 0.68 \\
\hline + New questions, views, perspectives & 2.84 & 0.7 \\
\hline $\begin{array}{l}\text { 1.5. Creative attitude: students desire and have a creative } \\
\text { consciousness. }\end{array}$ & 3.04 & 0.74 \\
\hline \multicolumn{3}{|l|}{$\begin{array}{l}\text { II. Development of Knowledge, Skills, Attitudes toward the } \\
\text { discipline and interdisciplinary }\end{array}$} \\
\hline $\begin{array}{l}\text { 2.1. Development of knowledge of the discipline and } \\
\text { interdisciplinary }\end{array}$ & 3 & 0.55 \\
\hline + Deep understanding of the discipline's knowledge & 3.42 & 0.76 \\
\hline + Development of the interdisciplinary knowledge & 2.59 & 0.74 \\
\hline 2.2. Development of skills of the discipline and interdisciplinary & 3.49 & 0.59 \\
\hline + Development of the discipline's skills & 3.51 & 0.76 \\
\hline + Development of the interdisciplinary skills & 3.18 & 0.75 \\
\hline $\begin{array}{l}\text { + Development of skills: communication, presentation, self-study, } \\
\text { teamwork ... }\end{array}$ & 3.8 & 0.78 \\
\hline 2.3 Consciousness, civic attitude & 3.52 & 0.59 \\
\hline $\begin{array}{l}\text { + Students work seriously, collaborate with other students and } \\
\text { teacher }\end{array}$ & 3.59 & 0.65 \\
\hline $\begin{array}{l}\text { + Students are aware of the good or limitations of the problem } \\
\text { they have learned to take the right action. }\end{array}$ & 3.46 & 0.89 \\
\hline \multicolumn{3}{|l|}{ III. Teaching Methods and Tools } \\
\hline $\begin{array}{l}\text { 3.1. Creative, diverse, integrated methods and tools enable } \\
\text { students to deepen knowledge and practice skill development. }\end{array}$ & 2.91 & 0.68 \\
\hline $\begin{array}{l}\text { 3.2. The teacher uses ICT fluently to save time and help students } \\
\text { to be more active, positive and creative. }\end{array}$ & 2.63 & 0.71 \\
\hline 3.3. The teacher uses the students' experiences & 3.46 & 0.8 \\
\hline
\end{tabular}




\begin{tabular}{|l|r|r|} 
3.4. The teacher uses real-life situations. & 3.34 & 0.8 \\
\hline $\begin{array}{l}\text { 3.5. The teacher encourages students to discuss and solve } \\
\text { problems with multiple solutions. }\end{array}$ & 2.46 & 0.71 \\
\hline IV. Forms of Teaching & 2.37 & 0.72 \\
\hline 4.1. The teacher uses individual and group forms & 2.78 & 0.73 \\
\hline V. Classroom Environment & 2.76 & 0.93 \\
\hline $\begin{array}{l}\text { 5.1. The teacher and students have a positive relationship during } \\
\text { school hours. }\end{array}$ & 2.56 & 0.75 \\
\hline $\begin{array}{l}\text { 5.2. The classroom has a positive and exciting psychological } \\
\text { atmosphere. }\end{array}$ & 4.06 & 0.87 \\
\hline $\begin{array}{l}\text { 5.3. The teacher and students listen to, respect, explore, and } \\
\text { support the diverse, different ideas that each student brings to the } \\
\text { class. }\end{array}$ & 3.65 & 0.79 \\
\hline $\begin{array}{l}\text { 5.4. The teacher ensures a good temperature and lighting in the } \\
\text { classroom }\end{array}$ & 2.38 & 0.63 \\
\hline VI. Classroom Management & 2.68 & 0.6 \\
\hline 6.1. Establishing behavioral rules in the classroom. & 3.48 & 0.66 \\
\hline $\begin{array}{l}\text { 6.2. The teacher observes, embraces students, and responds to } \\
\text { students' different needs and abilities. }\end{array}$ & 3.84 & 0.78 \\
\hline $\begin{array}{l}\text { 6.3. The teacher praises the good behavior and success of the } \\
\text { students }\end{array}$ & 3.21 & 0.98 \\
\hline VII. Assessment of Learning Outcomes & 3.37 & 0.8 \\
\hline 7.1. The teacher uses different types of assessment & 3.46 & 0.66 \\
\hline $\begin{array}{l}\text { 7.2. There is a combination of teacher assessment with student } \\
\text { assessment. }\end{array}$ & 0.56 \\
\hline 7.3. The teacher provides public assessment criteria and results. \\
\hline $\begin{array}{l}\text { 7.4. The teacher ensures value, reliability, fairness and efficiency in } \\
\text { the assessment process. }\end{array}$ & $\begin{array}{l}\text { 7.5. The teacher appreciates creative ideas, products, and valuable } \\
\text { practical applications. }\end{array}$ & 3.46 \\
\hline 7.6. The teacher asks the students to respect each other's ideas. & & \\
\hline
\end{tabular}

1- Very Poor, 2- Poor, 3- Acceptable, 4-Good, and 5-Very good. 